J. Product. \& Dev., 19(1):101 - 112 (2014)

\title{
BIOLOGICAL CONTROL ACTIVITY OF Trichoderma spp. AGAINST Phytophthorainfestans in vitro
}

\section{M.F. Salem ${ }^{1}$ *; Emara, H.A. ${ }^{1}$ and Shalaby, M.A. ${ }^{2}$}

1* Department of Environmental Biotechnology, Genetic Engineering and Biotechnology Research Institute, GEBRI, University of Sadat City, Egypt.

2 Department of Plant Biotechnology, Genetic Engineering and Biotechnology Research Institute, GEBRI, University of Sadat City, Egypt.

\section{ABSTRACT}

The biocontrol potential of Trichoderma sppagainsttomatolate blight pathogen i.e. Phytophthorainfestans was studied in vitro. Antagonism test was carried out between Trichoderma spp and P. infestans and showed a radial growth inhibition of the pathogen, and a complete overgrowth ofTrichoderma spponP. infestans.

Moreover, the biocontrol agentTrichoderma spp significantly reduced the disease.

In conclusion, from these results, it could be concluded that the biocontrol agents Trichodermasppcould be used efficientlyfor the suppression of the late blight causer organism P.infestans.

Keywords: Biological control, tomatolate blight, Phytophthora infestans, Trichoderma spp.

\section{INTRODUCTION}

Late blight disease caused by the pathogen Phytophthorainfestans, is probably the single most important disease of potatoes and tomatoes worldwide (Son et al., 2008).Disease was first recognized and became infamous in the mid-19th century, as it was responsible for many devastating epidemics, including the epidemic in Ireland which led to the great potato famine in 18451846, Worldwide losses due to late blight are estimated to exceed $\$ 5$ billion annually and thus the pathogen is regarded as a threat to global food security (Latijnhouwers et al., 2004). In the past few decades, the frequency and severity of the disease have increased in many parts of the world including Egypt and have been a serious 
threat to Potato production. Despite the fact that much of the success in controlling the disease hasbeen due to the application of large quantities of chemical fungicides, theirextensive use is causing a serious pollution problem in the environment (Ragunathan and Divakar, 1996). Further, the chemical control of late blight is becoming more difficult due to the appearance of new and more aggressive $P$. infestansstrains (Fernandez-Northcote et al., 2000).

Thus, an alternative control strategy such as biological control should be sought (Ellis et al., 1999). Biological control of crop disease is receiving increased attention as an eco-environmentally sound alternative to chemical pesticides. Some species ofTrichoderma are among the major microorganisms that haveshown great potential for biological control of several plant pathogens. Trichoderma species have shown biocontrol potential against many plantpathogens including diseases caused by Sclerotinia minor (Jones and Stewart, 1997; Dolatabadi et al., 2011), Botryosphaeriaberengerianaf. spp. piricola, Cladosporiumher barum (Barbosa et al., 2001), Dioscorea spp. (Okigbo and Ikediugwu, 2000) and Pythiumultimum (Naseby et al., 2000). Besides, Trichoderma species have also shown efficacy against diseases caused by Rhizoctoniasolani, Pythiumaphanidermatium, Fusariumoxysporum, Fusariumculmorum, Gaeumannomycesgraminis var. tritici, Sclerotiumrolfsii, Phytophthoracactorum, Botrytis cinerea and by Alternaria spp. (Kucuk and Kivanc, 2003) and Phytophthorainfestans.

However, significant studies on biological control of late blight of tomato are scarce and hence the main aim of this study was to evaluate the efficacy of local isolates, Trichoderma spp against late blight of tomato in vitro .

\section{MATERIALS AND METHODS}

\section{1-Phytophthora samples:}

Sample of infected tomato leaves were collected from an open filed naturally infected for isolation of the causal pathogen. These infected tomato samples were mainly collected from open fields during fall and winter seasons, 2012 .These infected tomato samples were collected from the open fields and kept in plastic bags until arrival to the laboratory in the same day. 
2-Trichoderma samples:

Different samples were collected from newly reclaimed areas in Egypt, Nobaria, Behera Governorate, Egypt, from rizhosphere of tomato, by digging up to $15 \mathrm{~cm}$ depth during October to December, 2012. These samples were obtained and collected in sterile plastic pots. The samples were transported to the laboratory in aseptic conditions. Trichoderma spp were isolated and maintained in PDA slant.

\section{3-Pea agar medium( PAM):}

Pea Agar Medium was consisted from $120 \mathrm{~g}$ frozen peas that were autoclaved for $15 \mathrm{~min}$ at $120 \mathrm{c}$ in 1 liter distilled water then pea broth were filtered using 4 layers of cheese cloth then squeezing gently to remove all excess liquid from peas. The volume was adjusted to 1 liter with distilled water and $20 \mathrm{~g}$ of agar was added and $10 \mathrm{~g}$ sucrose sugar then the medium was autoclaved again for $20 \mathrm{~min}$. at 15 psi.

\section{4-Potato dextrose agar medium (PDA):}

Potato Dextrose Agar medium (PDA) prepared as follows by cutting2oo g potato to small pieces and autoclaved for $20 \mathrm{~min}$. at $120 \mathrm{c}$ in 1 liter water then filtered using 4 layers of cheese cloth to remove all excess liquid from Potato then volume was adjusted to 1 liter and $12 \mathrm{~g}$ of agar was added and $10 \mathrm{~g}$ dextrose then the medium was autoclaved again for $30 \mathrm{~min}$. at 15 psi then allow pea and PDA medium to cool down to $40 \mathrm{c}$ before adding the mix of Antibiotics under sterile conditions mix of antibiotics added to culture medium (per liter).

- Ampicillin:100 mg dissolve in ml sterile water.

- Mycostatin: $50 \mathrm{ml}$ dissolve in $1 \mathrm{ml}$ sterile water .

- Pentachloronitrobenzene (PCNB): $10 \mathrm{mg}$ dissolve in $\mathrm{ml}$ Dimethyl sulfoxide (DMSO).

- Rifampicin: $10 \mathrm{mg}$ dissolve in $1 \mathrm{ml}$ (DMSO).

\section{5-Isolation and identification of four Trichoderma spp}

Fungal isolates of Trichoderma spp were isolated from soil samples by using Potato Dextrose Agar (PDA) medium. Samples were inoculated over plates by Multiple Tube Dilution Technique (MTDT) and the plates were incubated at $23^{\circ} \mathrm{C}$ for 5 days. The fungal colonies which were picked up and purified by inoculating and incubated at $23^{\circ} \mathrm{C}$ for 9 days. Green conidia forming fungal bodies were selected and identified through microscopic 
observation to be Trichoderma spp. The culture was maintained on PDA slantsA 4mm disc of inoculum from sub cultured plates of Trichoderma spp were transferred to Potato Dextrose Agar(PDA) slants and maintained as pure culture.

The plates were then incubated at room temperature $\left(26 \pm 2^{\circ} \mathrm{C}\right)$ for ten days. After complete sporulation, conidia from the medium were harvested by washing them thoroughly with sterilized water containing Tween-20 $(0.2 \%)$ for immediate useHarvested conidia were air dried under laminar air flow and stored in a small air tight screw cap vials $(10 \mathrm{~cm}$ with $2.5 \mathrm{~cm}$ diameter) in refrigerator at $4^{\circ} \mathrm{C}$ before using for further studies. Colony Forming Units (CFU)were estimated by plating technique Suspension of spores was made using sterilized distilled water with Tween-20 (0.2\%) and filtered through a double layered muslin cloth. Spore count was made using a double rolled Neuberger's Haemocytometer after necessary serial dilutions under phase contrast microscope. From the stock solution, dilutions were made to obtain the required concentrations.

\section{6-Isolation of Phytophthora infestans from infected tomato leaves:}

Isolation of the causal organism Phytophthora infestans was isolated from the infected leaf tissues according to the following protocol:

1. Sporulation lesions on leaf tissue from the field were washed in fresh water and placed in a humid chamber with the leaf `s abaxial side up.

2. Plates were incubated at $15-18 \mathrm{c}$ with a 14 hour light period for 1 day or until sporulation appears.

3. Small pieces of infected tissue from the sporulating border of lesion were cut out and placed on top of a drop of water on the abaxial side of tomato leaves in a humid chamber (upturned Petri dish containing water agar).

4. Dishes were incubated at room temperature for 1 Week or until there is abundant sporulation.

5. Sporangia were picked from the top of tomato leaves and transferred directly onto medium in a petri dish containing rye agar with antibiotics.

\section{7-Antagonistic test between Trichoderma spp and P. infestans:}

Dual culture method was employed to analyze whether Trichoderma spp inhibits the growth of $P$. infestansas described in Sivakumar et al. (2000). Briefly, $1 \mathrm{~cm}$ diameter mycelial plug of $P$. infestans (7 days old) was placed on one side of a petri-dish (9 $\mathrm{cm}$ diameter) containing pea agar and preincubated at $23 \mathrm{C}$ for 2 days to initiate growth. Later, $1 \mathrm{~cm}$ diameter disc of Trichoderma spp (5 days old) was placed $6 \mathrm{~cm}$ away from the pathogen on 
the dual plates; whereas sterile PDA disc was placed in the control plates. The assay was done in five replicatesand the radial growth of the pathogen was measured 4 days after incubation at $23 \mathrm{C}$.

The percent radial mycelial growth inhibition (I) was calculated as follows:

$$
\mathrm{I}=[(\mathrm{C}-\mathrm{T}) / \mathrm{C}] \times 100 \text { according to Sivakumaret al., 2000; }
$$

Where, $\mathrm{C}$ is radial growth measurement of the pathogen in the control plates and $\mathrm{T}$ is radial growth of the pathogen in the dual plates.

\section{8- Assay for volatile metabolites of Trichodermaspp:}

Bottoms of two Petri dishes containing PDA were individually inoculated with a disc of $P$. infestans and Trichoderma spp. The bottoms were adjusted (one base placed over the other one) and attached by Para film. The control sets did not contain the antagonist. The cultures were incubated at room temperature $\left(23 \pm 2{ }^{\circ} \mathrm{C}\right)$, and diameter of radial growth of fungi was measured at 24 and 48 hours. The percent inhibition was obtained using the formula as follows:

Percent inhibition $(\mathrm{I})=\mathrm{C}-\mathrm{T} / \mathrm{C} \times 100$

Where, C: Diameter of radial growth of $P$. infestans in control; $\mathrm{T}$ :Diameter of radial growth of $P$. infestans in treatment.

\section{9-Extracted metabolites of T.viride and T.harzinum against P.infestans:}

The purified sterile metabolites of Trichoderma spp. were diluted four times, and their inhibitory effect was tested. $1 \mathrm{ml}$ of the original and dilutions $\left(10^{-1}, 10^{-2}, 10^{-3}\right.$, and $\left.10^{-4}\right)$ of the extracts were mixed with $20 \mathrm{ml}$ of molten PDA separately and then poured into Petri dishes. PDA supplemented with sterile distilled water served as control. A mycelia disc of P. infestans was transferred on the centre of both test and control plates and incubated for 24 hours at room temperature. The linear growth of mycelia was measured and the percentage of inhibition was calculated. Same procedures were applied for metabolites extracted from $P$. infestans against Trichoderma spp.

\section{Statistical analysis:}

Statistical significance of antagonistic effect of Trichoderma spp. was tested by ' $\mathrm{t}$ ' test $(\mathrm{P}=0.05)$, results produced by the Trichoderma spp. were expressed as mean $\pm \mathrm{SD}$ of three experiments, and were subjected for analysis of variance and Tukey test at $\mathrm{P}=0.05$ using statistical software SPSS Windows version 13.0. 


\section{RESULTS}

The results of dual culture of Trichoderma antagonists and the causal pathogen Phytophthora infestance demonstrated that the antagonists were significantly different from control as well as within them. Moreover, both $T$. virideand T. harzianum had an antagonistic effect on $P$. infestance. Whereas, $T$. harzianum highly inhibited the growth of test pathogen compared to $T$. viride, and the percentage of inhibition increased about two times to T. viride (Table1). Moreover, we have to mention that $T$. hamatum has the highest percentage of inhibition after 3 days of interactions compared with other biocontrol agents (Table 2).

Table 1: Effect of FourTrichoderma spp. on the radial growth of $P$. infestans in dual culture method after $48 \mathrm{hrs}$.

\begin{tabular}{|c|c|c|c|}
\hline \multirow[t]{2}{*}{ Antagonists } & \multicolumn{2}{|c|}{ Radial growth at 48 hours } & \multirow{2}{*}{$\begin{array}{c}\text { Inhibition, } \\
\%\end{array}$} \\
\hline & Control, mm & Test, mm & \\
\hline T.virde & \multirow{4}{*}{$\begin{array}{l}79.34 \\
82.15 \\
79.19 \\
72.10\end{array}$} & 62.42 & 21.32 \\
\hline T.atrovride & & 59.98 & 26.98 \\
\hline T.harzianum & & 50.21 & 36.59 \\
\hline T.hamatum & & 50.16 & 30.42 \\
\hline
\end{tabular}

Table 2: Effect of four Trichoderma spp. on the radial growth of P. infestans in dual culture method after $72 \mathrm{hrs}$.

\begin{tabular}{|l|c|c|c|}
\hline \multirow{2}{*}{ Antagonists } & \multicolumn{2}{|c|}{ Radial growth at 72 hours } & Inhibition, \\
\cline { 2 - 3 } & Control, mm & Test, $\mathbf{~ m m}$ & \\
\hline T.virde & 88.63 & 51.13 & 42.31 \\
\hline T.atroviride & 89.40 & 49.11 & 45.06 \\
\hline T.hariznuim & 90.20 & 55.78 & 38.15 \\
\hline T. hamatum & 88.70 & 37.24 & 58.01 \\
\hline
\end{tabular}

The volatile metabolites of $T$. harzianumand $T$. hamatum showed the highest significant growth inhibition against $P$. infestance at 24 hours incubation. The inhibition produced by the $T$. viride was significantly the lowest among the tested biocontrol agents (Table 3 ). 
Table 3: Effect of volatile metabolites of four Trichoderma spp. on the radial growth of $P$. infestans after 24 hours.

\begin{tabular}{|c|c|c|c|}
\hline \multirow[t]{2}{*}{ Antagonists } & \multicolumn{2}{|c|}{ Radial growth at 24 hours } & \multirow{2}{*}{$\begin{array}{c}\text { Inhibition, } \\
\%\end{array}$} \\
\hline & Control, mm & Test, mm & \\
\hline T.viride & \multirow{4}{*}{$\begin{array}{l}60.67 \\
60.20 \\
60.67 \\
64.30\end{array}$} & 43.71 & 27.95 \\
\hline T.atroviride & & 40.45 & 32.80 \\
\hline T.harzianum & & 31.14 & 48.67 \\
\hline T. hamatum & & 42.32 & 34.18 \\
\hline
\end{tabular}

Trichoderma spp showed no significant difference between the radial growths of $P$. infestans in test and in control plates at 48 hours incubation and $0 \%$ inhibition. But T.atroviride significant $0.29 \%$ (Table 4).

Table 4: Effect of volatile metabolites of Trichoderma spp. on the radial growth of $P$. infestans after 48 hours.

\begin{tabular}{|c|c|c|c|}
\hline \multirow[t]{2}{*}{ Antagonists } & \multicolumn{2}{|c|}{ Radial growth at 48 hours } & \multirow{2}{*}{$\begin{array}{c}\text { Inhibition, } \\
\%\end{array}$} \\
\hline & Control, mm & Test, mm & \\
\hline T. viride & \multirow{4}{*}{$\begin{array}{l}89.24 \\
89.20 \\
89.24 \\
89.24\end{array}$} & 89.24 & 0.0 \\
\hline T. atroviride & & 88.98 & 0.29 \\
\hline T. harzianum & & 89.24 & 0.0 \\
\hline T. hamatum & & 89.24 & 0.0 \\
\hline
\end{tabular}

Radial growth of P. infestans in control $70.24 \mathrm{~mm}$.

Trichoderma spp. extracted metabolite's was revealed the inhibitive bioactivity on the growth of $P$. infestans. However, the inhibitory effect produced by the $T$. viride is slightly higher than that produced by $T$. harzianum. and, both extracts showed inhibition even at 10000 time dilution. the results of extracted metabolites of $P$. infestans did not show any inhibition against the growth of Trichoderma spp. (Table 5).

\section{DISCUSSION}

Late blight, caused by the oomycete pathogen Phytophthorainfestans, is probably the single most important disease of potatoes worldwide and Egypt as well. We suffer from this fatal potato disease all over Egypt. It is destructive 
Table 5. Effect of extracted metabolites of T.viride and T.harzianum.on the radial growth of $P$. infestans.

\begin{tabular}{|c|c|c|c|}
\hline Antagonists & Dilutions & $\begin{array}{c}\text { Diameter of radial } \\
\text { growth }\end{array}$ & $\begin{array}{c}\text { Inhibition } \\
\text { \% }\end{array}$ \\
\hline \multirow{4}{*}{ T. harzianum } & 10 & 36.9 & 47.46 \\
\cline { 2 - 4 } & $10-1$ & 39.25 & 44.12 \\
\cline { 2 - 4 } & $10-2$ & 41.9 & 40.43 \\
\cline { 2 - 4 } & $10-3$ & 40.63 & 42.15 \\
\cline { 2 - 4 } & $10-4$ & 44.49 & 36.66 \\
\hline \multirow{4}{*}{ T. viride } & 10 & 30.0 & 57.28 \\
\cline { 2 - 4 } & $10-1$ & 35.25 & 49.81 \\
\cline { 2 - 4 } & $10-2$ & 36.33 & 48.27 \\
\cline { 2 - 4 } & $10-3$ & 37.73 & 46.28 \\
\cline { 2 - 4 } & $10-4$ & 41.31 & 41.18 \\
\hline
\end{tabular}

wherever potatoes are grown without the use of fungicides, except in hot, dry, and irrigated areas (Thurston and Schultz, 1981). Biological control is a good alternative for sustainable agriculture to overcome the problems of public concern associated with pesticides and pathogens resistant to chemical pesticides and to become eco-friendly (Akhtar and Siddiqui, 2008). In this study Trichoderma spphas been found to retard the radial growth of $P$. infestans. This antagonistic mode of action of Trichoderma could be attributed to the production of antibiotics and fungal cell wall degrading enzymes (Chutrakuletal., 2008; Sharma et al., 2009). A similar inhibitory action of Trichoderma strains (TH1, N47 and T12) against a related oomycete pathogen, Pythiumultimum, was reported earlier (Naseby et al., 2000). The observed mycoparasitic action of Trichoderma in this study suggests that it has a good potential in controlling $P$. infestans. Similar mycoparasitic action of Trichoderma strains were also reported against related pathogens, Phytophthoracinnamomi (Pugeg and Ian, 2006) and Phytophthoracapsici (Ezziyyani et al., 2007) Trichoderma species were found to give better control of Botryosphaeriaberengerianawhen inoculated three days in advance than when the two are co-inoculated. Germination of fungal spores on the leaf surface is a critical stage in the development of the host-pathogen interface, and one in which the pathogen is often vulnerable (Campbell, 1989). The motile zoospores of $P$. infestanshave no cell wall and hence are probably extremely vulnerable to adverse conditions, and are also 
the main infective propagules (Erwin and Ribeiro, 1996). Thus, zoospores can be a potential target in biocontrol of $P$. infestans. In conclusion, Trichoderma spp showed good potential in controlling potato late blight under in vitro conditions. In addition to that, the Trichoderma spp used in this study was isolated from local climatic conditions in Egypt and effectively proved that it has potential to be used as a biocontrol agent in the future. The non-volatile metabolites of $T$. virideand $T$. atroviride showed the highest significant $(\mathrm{P}<0.05)$ growth inhibition against $P$. infestanceat 24 hours incubation. The inhibition produced by the $T$. harzianum was significantly ( $\mathrm{P}$ $<0.05)$ the lowest among the tested biocontrol agents and this leads us to its optimum way of application in greenhouse and open field conditions through producing its metabolites directly to the infected soil , as both T.viride and T.atroviride worked as a biocontrol agents with a unique antagonism mechanism called antibiosis compared with T.harzianum which antagonize the causal pathogen with the mechanism of mycoparasitism. This is lead us to put into consideration its practical and efficient way during application either greenhouse or under open field conditions. Further research is needed to determine its field performance. In general, as any other biological control systems, biological control of late blight should be regarded as one of the safest technology of the integrated control program rather than a method to be used alone.

In conclusion, from these results, it could be concluded that the biocontrol agents Trichoderma spp could be used efficiently for the suppression of the late blight causer organism $P$. infestans.

\section{REFERENCES}

Akhtar, M.S and Siddiqui, Z.A. (2008).Arbuscularmycorrhizal fungi as potential bioprotectants against plant pathogens.Mycorrhizae: Sustainable Agriculture and Forestry, 61-97.

Barbosa, M.A.G., Rehn, K.G., Menezes, $M$ and Mariano, R.L. (2001).Antagonism of Trichoderma species on Cladosporium herbarium and their enzymatic characterization. Brazilian Journal of Microbiology, 32: 98-104.

Chutrakul, C., Alcocer, M., Bailey, $K$ and Peberdy, J.F. (2008). The production and characterization of Trichotoxinpeptaibols by Trichoderma asperellum. Chemistry and Biodiversity, 5: 1694- 1706. 
Dolatabadi, K.H., Goltapeh, E.M., Varma, A and Rohani, N. (2011).In vitro evaluation of arbuscularmycorrhizal-like fungi and Trichoderma species against soil borne pathogen. Journal of Agricultural Technology, 7(1): 73-84.

Campbell,R.(1989). Biological Control Of Microbial Plant Pathogens. Cambridge University Press, Cambridge, 232 pp.

Ellis, R.J., TimmsWilson, T.M., Beringer, J.E., Rhodes, D., Renwick, A., Stevenson, L and Bailey,M.J.(1999).Ecological busis for biocontrol of damping off disease by pseudomonas fluorecens 54/96. Journal of Applied Microbiology, 87:454-463.

Erwin,D.C and Ribeiro, O. K., 1996. Phytophthora disease worldwide. American Phytopathological Society, Minnesota, 562 pp.

Ezziyyani, M.; Reguena, M. E.; Egea-Gilabert; Cand Candela, M. E. (2007). Biological control of phytophthora root rot of pepper using Trichoderma harzianum and Streptomyces rochei in combination. Journal of phytopathology, 155:342-349.

Fernandez-Northcote, E.N., Navia, O and Gandarillas, A. (2000). Basis of strategies for chemical control of potato late blight developed by PROINPA in Bolivia. Fitopatologia, 35: 137-149.

Jones, E. E. and Stewart, A. (1997). Biological control of Sclerotinia minor in lettuce using Trichoderma species. Proc. New Zealand Plant Protection Conf., 50:154-158.

Kucuk, C and Kivanc, M. (2003).Isolation of Trichoderma spp. and determination of their antifungal, biochemical and physiological features. Turkish Journal of Biology, 27: 247- 253.

Latijnhouwers, M., Ligterink, W., Vleeshouwers, V.G., VanWest, P and Govers, F. (2004). AGa subunit controls zoospore mobility and virulence in the potato late blight pathogen Phytophthorainfestans. Molecular Microbiology, 51: 925-936.

Naseby, D.C., Pascual, J.A and Lynch, J.M. (2000).Effect of biocontrol strains of Trichoderma on plant growth, Pythiumultimumpopulations, soil microbial communities and soil enzyme activities. Journal of Applied Microbiology, 88: 161-169.

Okigbo, R.N and Ikediugwu, F.E.O. (2000). Studies on biological control of post-harvest rot in yams (Discoreaspp.) using Trichoderma viride. Journal of Phytopathology, 148: 351-355. 
Pugeg, I.N.A and Ian, D.G. (2006).Mycoparasitic and antagonistic inhibition on Phytophthoracinnamomirands by microbial agents isolated from manure composts. Plant Pathology 5: 291- 298. Journal of Agricultural Technology 2011, 7 (6): 1589-1602 1602

Ragunathan, V and Divakar, B.J. (1996).Integrated pest management strategies. In: Molecular biology of the biological control of pests and disease of plants. ed. by M. Gunasekaran and D. J. Weber, pp.191-194. CRC Press, Florida.

Sharma, K., Kumar, M and Misra, R.M. (2009). Morphological, biochemical and molecular characterization of Trichoderma harzianum isolates for their efficacy as biocontrol agents. Journal of Phytopathology, 157: 51-56.

Sivakumar, D.; Wijeratnam, W.R.S.; Wijesundera, R.L.C.; Marikar, F.M.T and Abeyesekere, M. (2000). Antagonistic effect of Trichoderma harzianum on post-harvest pathogens of Rambutan (Napheliumlappaceum). Phytoparasitica 28: 240-247.

Son, S.W., Kim, H.Y., Choi, G.J., Lim, H.K., Jang, K.S., Lee, S.O., Sung, N.D and Kim, J.C. (2008).Bikaverin and fusaric acid from Fusariumoxysporumshow antioomycete activity against $P$. infestans.Journal of Applied Microbiology 104: 692-698.

Thurston, H.D. and Schultz, O. (1981).Late blight. In: Compendium of potato diseases, pp. 40-42, (Hooker, ed). American Phytological Society, U.S.A. 


\title{
دراسة تأثير التضاد الحيوي لفطر تريكوديرما ضد فطر الفيتوفثرا انفيستنس فى المعل
}

\author{
الالسماء واماكن العمل
}

أجرى هذا البحث فى معمل امراض النبات بقسم التكنولوجيا الحيوية النباتية بمعهة

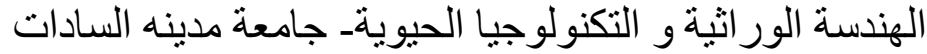

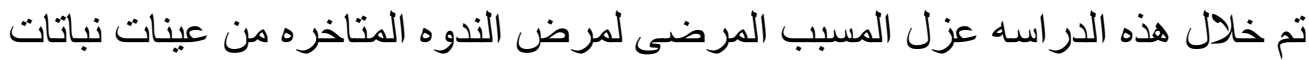

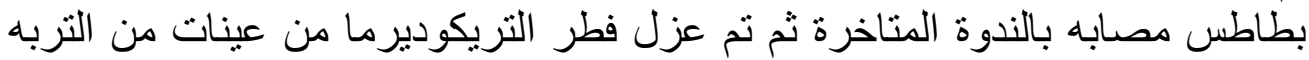

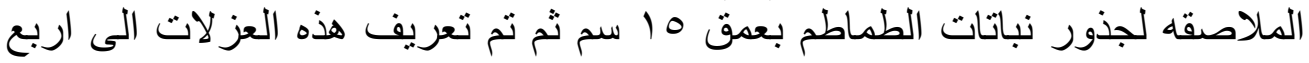

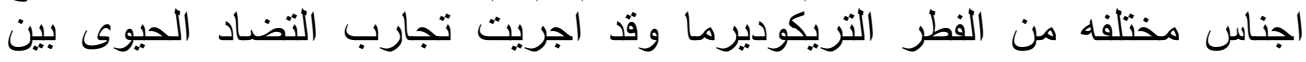

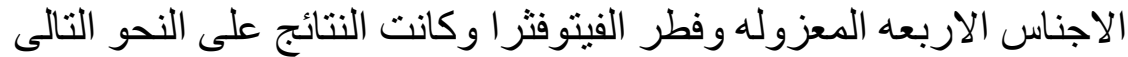

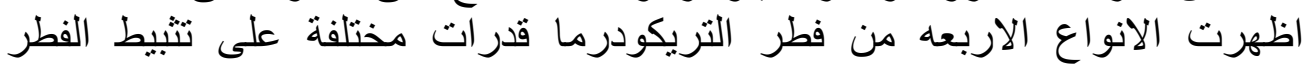

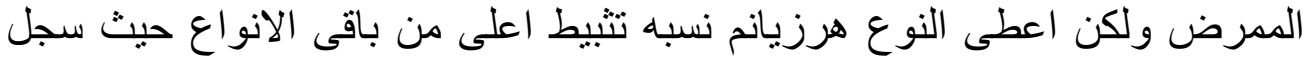

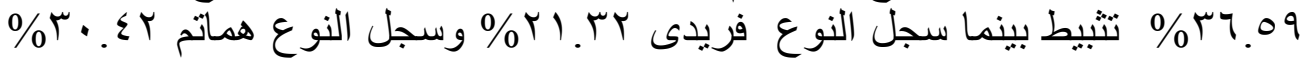

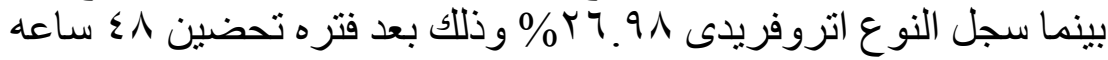

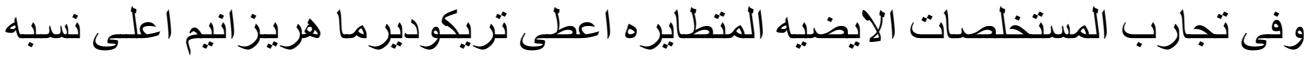

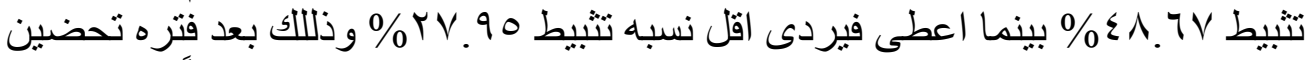

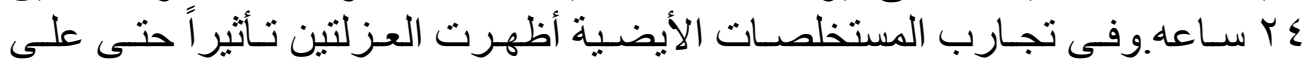

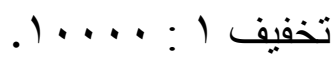

